\title{
Adoption pattern and constraint analysis for achieving potential productivity of irrigated and rainfed rice ecosystems in Andhra Pradesh
}

\section{Y. SUDHA RANI', G. JAYASREE ${ }^{2}$, K.C.NATARAJA ${ }^{1}$, M. JAYA LAKSHMI' AND K. SUPRIYA ${ }^{3}$}

\author{
${ }^{1}$ Central Research Institute for Dryland Agriculture (CRIDA), Hyderabad-59 \\ ${ }^{2}$ Department of Soil Science and Agricultural Chemistry, ANGRAU, Hyderabad-30 \\ ${ }^{3}$ Department of Statistics and Mathematics, ANGRAU, Hyderabad-30
}

\begin{abstract}
The present study was carried out during 2010-11 at Department of Soil Science and Agricultural Chemistry, College of Agriculture, Rajendranagar, ANGRAU, Hyderabad to prioritize the constraints causing yield loss in both irrigated and rainfed rice. A study had conducted on 60 farmers in irrigated rice ecosystem and $\mathbf{3 0}$ farmers from rainfed ecosystem of Andhra Pradesh. It was found that the soil related constraints faced by farmers ranked from more to less serious and the constraints were related to low fertility of soil, inadequate organic matter, problem soils and multi nutrient deficiencies of the soils. Under crop management related constraints, it was found that adopting specific fertilizer application method, availability of improved variety, inadequate supply of water, infestation of weeds and higher pest incidence were the most serious constraints perceived by large percentage of farmers. In case of socio-economic constraints, the study found that the poor infrastructure, high cost of inputs, availability of credit, low price for the produce, inadequate inputs and lack of trainings were the most important constraints as perceived by large percentage of farmers. Other constraints as perceived by lower percentages of farmers were poor extension services, lack of information and lack of support from local authorities or government.
\end{abstract}

\section{Key words: Irrigated rice, Rainfed rice, Production constraints}

Rice is the staple food of more than 60 per cent of the world's population and majority in the South-East Asia. Rice is the most important crop of India, covering an area of about $42.56 \mathrm{M}$ ha with an annual production of 95.33 Mt and productivity of $2240 \mathrm{~kg} \mathrm{ha}^{-1}$ during 2010-11. The country is ranking first and second with respect to area and production and twenty eight position with respect to productivity of rice in the world. Rice occupies about 23.3 per cent of gross cropped area of the country and plays a vital role in the national food grain supply. In Andhra Pradesh rice is cultivated in an area of $2.68 \mathrm{M}$ ha during kharif and 1.2 $\mathrm{M}$ ha during rabi seasons in 22 districts of the state with an annual production of 63.93 lakh tones and productivity of $2100 \mathrm{~kg} \mathrm{ha}^{-1}$. Rice productivity fluctuates significantly from region to region due to various factors such as pest and diseases, soil type, soil fertility, rainfall pattern, flood, drought, water logging and variable climatic conditions.

Therefore the approach should be to identify the constraints which operate to keep rice yields significantly high and maintain the yield gap. Choudhary and Tran (1999) approaches to bridge the gap of projected demand to current level of production could be done through the expansion of rice cultivated area (horizontal expansion), improving yield (vertical expansion), and reducing yield losses. The increase in production of rice not only come from expansion of area under rice cultivation or identifying suitable rice production technologies due to competing use of land from other sectors and environmental concerns. Possible avenues for growth in yield and production would depend to a large extent on exploring ways by which yield per land area could be increased and also removing the constraints of rice production to achieve high yield for each production ecosystem and location by yield gap analysis. Removing constraints to yield is not synonymous with outright increase in production. It must be backed with some level of commitment in terms of adoption of improved farming methods, improved technologies, research, credit and extension support given to farmers. The extent to which any of these commitments contribute to low yields will vary from one production ecosystem to another; hence the need has been arise to carry out a survey to identify the constraints associated with each production system. This paper aims at understanding the problems and constraints faced by farmers in rice production of different rice ecosystems. The constraints of the farmers were focused in three problems viz. soil related constraints, crop management related constraints and socio-economic constraints for understanding the real situations in rice production of Andhra Pradesh, which are useful to find out the suitable solutions for overcoming the constraints and achieving high and sustainable yields in rice production.

\section{MATERIALS AND METHODS}

Study area

Three districts of Andhra Pradesh selected for the present study. Guntur and Nalgonda are the two districts, where rice area of 2.77 and 1.47 lakh ha produced 8.49 and 4.18 lakh tonnes of rice production under irrigated condition, respectively in Andhra Pradesh. Because of the suitable soils and good irrigation facility almost all the farmers in the region are growing two crops of rice per 
year with the rice yield per ha relatively high. The other district Visakhapatnam where rice is grown in an area of 0.96 lac ha with the production of 1.42 lac tones under rainfed condition selected for the study.

\section{Selection of farmers}

There were 60 farmers selected from the two districts viz., Guntur and Nalgonda where rice is growing under irrigated conditions and 30 farmers selected from Visakhapatnam district where rice is cultivated under rainfed conditions.

\section{Measurement of the constraints}

There is no single best method for identifying Farmers constraints and research needs. A personal survey helps to identify some constraints. The information on constraints faced in rice production by farmers was collected with the help of interview schedules. The major constraints taken into account were technical, socioeconomic and soil related constraints. To help in the constraint analysis, a comprehensive list of socioeconomic, technical and soil related constraints was given to farmers. The respondents were asked to express the constraints as per the severity felt by them and the scores are analyzed based on majority of responses as obtained and ranked on the basis of the importance.

The data thus selected from the sample respondents through interview schedules were coded, tabulated, analyzed and presented in the form of tables in order to make the findings meaningful and easily understandable. The findings emerged from the analysis of data were suitably interpreted and necessary conclusions and inferences were drawn. The frequencies and percentages were calculated in documentation of production constraints. The percentage analysis was done to make simple comparisons wherever necessary.

\section{RESULTS AND DISCUSSION}

Rice yields in Andhra Pradesh fluctuate greatly in time and space on account of its cultivation under diverse weather, ecological and socioeconomic conditions. 94 per cent of the area is under irrigated condition and remaining 6 per cent of the area is under rainfed conditions often affected by erratic weather aberrations. Constraints responsible for lower yields are majorly technical and socioeconomic Paroda (1998). Major constraints in each rice ecosystem along with the details of selected farmers are indicated below

\section{Profile of the selected farmers}

\section{Land holding}

The data (Table 1) shows that with respect to size of the land holdings, marginal, small and big farmers accounted for an equal percentage $33.34 \%, 33.33 \%$, $33.33 \%$, respectively and an equal number of farmers were selected from each category.

\section{Area of rice cultivation and cropping pattern}

With regard to the area under rice cultivation in irrigated ecosystem, the low (13.34\%), medium $(13.33 \%)$ and high $(73.33 \%)$ categories and in rainfed ecosystem the low $(23.30 \%)$, medium $(33.33 \%)$ and high $(43.33 \%)$ categories. With respect to cropping pattern, it was observed that all the farmers in irrigated ecosystem practiced a single crop of rice followed by $13.3 \%$ practiced double crop of rice. Where as in rainfed ecosystem all the farmers practiced a single crop of rice.

\section{Social participation}

In irrigated ecosystem, with regard to social participation of the rice growers, the trend of the farmers participation in the social commitments which are related to their farming activity was observed in the fallowing manner that the $50 \%$ belong to medium level of social participation followed by $26.7 \%$ and $25.40 \%$ in low and high level of participation respectively. In rainfed ecosystem, $40 \%$ represents low level of social participation, $26.7 \%$ represents medium and $33.3 \%$ represents high level of social participation.

\section{Economic motivation and information seeking behavior} of the farmers

In irrigated rice ecosystem, with respect to the economic motivation it was observed that $36.7 \%$ comes under low category of economic motivation followed by $33.3 \%$ of medium economic motivation and $30.3 \%$ comes under high category of economic motivation. In rainfed rice ecosystem, the trend observed that $53.3 \%$ comes under low category followed by $23.3 \%$ each of medium and high economic motivation (Table 1 ).

As far as the information seeking behavior is concerned, in irrigated rice ecosystem $30.0 \%$ of the farmers belonged to low level followed by 33.3 per cent in the medium level and 36.7 per cent belong to high level and in rainfed ecosystem, 63.3 per cent of the respondents belonged to low level followed by 20.0 per cent in the medium level and 16.7 per cent belong to high level of seeking information behaviour.

\section{Labour availability}

In irrigated ecosystem about $71.7 \%$ of the farmers had medium level of labour availability, $21.67 \%$ had low level of labour availability and only $6.63 \%$ farmers getting high level of labour availability for their farming activities. In rainfed ecosystem most of the respondents $50.0 \%$ had low level of labour availability, 26.7\% medium level of labour availability and $23.3 \%$ of the farmers getting high level of labour availability for their cultivation activities.

\section{Adoption behavior of farmers on recommended practices}

\section{Variety and seed rate}

Majority of the farmers about $88.3 \%$ in irrigated rice cultivation sowed with the recommended varieties in their region while in rainfed area $70.0 \%$ of the farmers adopted the recommended variety. But in case of both irrigated and rainfed rice cultivation about $66.7 \%$ of the farmers fallowed the recommended seed rate. The reason could be for the rest of the farmers in both the may be attributed to the reason that they were not willing to take risk of loss of plant population while raising their own nursery and the possibility of loss of seedlings during germination due to heavy rain, pest and disease attack and other reasons. Most of the farmers expressed that they could not afford to take risk due to poor germination of own seeds, pest and disease and root snapping problem during pulling of seedling (Table 2). 


\section{Soil test and fertilizer recommendation}

It is observed that $25.0 \%$ in irrigated and $23.3 \%$ in rainfed are responded to application of fertilizers based on soil testing. $50.0 \%$ of the farmers applied fertilizer in split in irrigated area and $33.3 \%$ in rainfed area. $48.3 \%$ of the farmers in irrigated and $36.7 \%$ in rainfed area were responded to micronutrient application (Table 2). Majority of the farmers had not adopted fertilizers based on soil test, Integrated Pest Management and micro nutrient application due to lack of technical knowledge, complexity of the practices, and non-realization of importance of these practices. The findings of the study were in agreement with the findings of Balasubramani et al. (2005).

Constraints faced by rice growing farmers in irrigated and rainfed conditions

\section{Soil related constraints}

The major soil related constraints faced by farmers in the production of paddy were low fertility of the soils, multinutrient deficiency in the soils, problem soils and inadequate organic matter. In irrigated rice ecosystem, $58.3 \%$ of the farmers responded to low fertility in soils and $30 \%$ of the farmers responded to problem soils. Where as in rainfed ecosystem $80 \%$ of the farmers facing low fertility in soils and $33.3 \%$ of the farmers facing different soil problems. In rainfed rice ecosystem, low soil fertility due to soil erosion resulting in loss of plant nutrients and moisture (Table 3).

\section{Crop management related constraints}

The crop related constraints faced by the framers are adopting specific fertilizer application method, infestation of weeds, higher pest incidence, and inadequate supply of irrigation water. Majority of the farmers applied fertilizers on blanket recommendation due to their lack of awareness and knowledge about recommended and dose of fertilizers (Table 3). Lack of suitable varieties with stress-tolerance at various stages of growth has been one of the limiting factors together with inadequate nutrition.

In rainfed rice, often crop suffers with soil moisture stress due to erratic and inadequate rainfall. In upland soils rain water flows down quickly and farmers are not able to conserve the soil moisture. There is also no facility for life saving irrigation particularly in upland areas. The scarcity of farm yard manure and green manure in upland areas, farmers depend heavily on the indiscriminate application of inorganic fertilizers to maintain productivity which leads to susceptibility of the crop to pests and diseases and also leads to deteriorating soil health. Heavy infestation of weeds and insect pests such as rice Blast disease and Brown spot resulted in reduction of yield drastically. In rainfed rice, the growth is mostly dependent on the well distribution of the rainfall. In case of scanty or adverse distribution of rainfall, the crop fails owing to drought and in the case of heavy rainfall, particularly during blossoming, there is poor grain setting and also the matured grains germinate on the panicles.

Herbicide application, pest and disease management maintaining plant population in nursery as well as in the main field were not adopted by the majority of the farmers.
Non availability of high yielding varieties, high cost of labour, and low fertility of the soils, Drought and lack of conviction in the new technology were the major constraints faced by the farmers. Therefore, it was necessary to intensify the extension efforts to increase their knowledge level and adoption of recommended rice technologies, which would help in increasing the yield of rice at farm level.

\section{Socio-economic constraints}

Among the major socio-economic constraints perceived by the farmers were high cost of labour, high cost of inputs, high rate of credit, non-availability of credit and scattered land holding. High cost of the high yielding variety seeds was expressed as a major constraint by $68.3 \%$ and $66.7 \%$ of the farmers in irrigated and rainfed rice ecosystems respectively (Table 3). Most of the farmers reported that they were not getting enough quantity of seeds for their entire cultivable land holding. It was also found that high yielding variety seeds produced and marketed by the State Government and other agencies were priced higher due to high production cost or because of other unknown reasons.

High cost of labour was expressed as a constraint by $76.7 \%$ of the respondents as the agricultural labourers were demanding higher wages irrespective of nature of work in irrigatrd ecosytems. Most of the farmers reported that the available farm labourers were not properly trained since most of the cultivation practices in rice farming right from sowing to post harvest require special skills. Veearswami et al. (2003) reported similar constraints perceived by the rice farmers of Cuttack and Puri districts of Orissa. Due to demand for labour at the peak period of crop, the major works like transplanting, broadcasting of seed, weeding and harvesting was carried out on contract basis. Leads to delay in carrying the practices, and also maintaining the optimum plant population was perceived as a difficult task due to timely unavailability of farm labours.

\section{Other constraints of rice growing farmers}

Other constraints perceived by the farmers were the absence of demonstration and lack of training facilities to the farmers from the agriculture officers or concerned authorities. These constraints were found to affect the dissemination of innovation and adoption of improved practices in paddy cultivation. Non-availability of desired technology was seen as a constraint by $60 \%$ of the farmers in rice cultivation of both irrigated and rainfed rice cultivation (Table 3). The recommended rice technologies may not be suitable to all the regions. The recommendations of State Department of Agriculture for obtaining higher yields may not be relevant to the site specific conditions. As a result, there is a possibility of reduction of yield at farm level due to various climatic and soil factors. With regards to adoption of recommended rice technologies in the farm, $56.7 \%$ and $63.3 \%$ of the farmers in both irrigated and rainfed conditions given the response that the lack of training facilities about certain technologies could be the reason for low adoption of the technologies. Similar results were reported by Singh and Varshaney (2010). 


\section{Conclusions}

With respect to the adoption behavior the new technologies and fallowing the recommended package of practices, the majority of the farmers showed medium level of overall adoption of recommended package of practices and technologies. Herbicide application, pest and disease management in nursery and main field, maintaining plant population in main field were not adopted by the majority of the farmers due to the various reasons mentioned earlier. With respect to the Constraints faced by the farmers in their cultivation practices the non availability of high yielding varieties, high cost of labour, lack of conviction in the new technology and weak extension activities at the village level were the major constraints faced by the farmers. Therefore, it was necessary to intensify the extension efforts to increase their knowledge level and adoption of recommended rice technologies, which would help in increasing the yield of rice at farm level as well as increase in productivity of the rice crop both in the irrigated and rainfed conditions.

\section{Table 1: Details of the selected farmers.}

\begin{tabular}{|c|c|c|c|c|}
\hline \multirow{2}{*}{ Variable } & \multicolumn{2}{|c|}{ Irrigated ecosystem $(n=60)$} & \multicolumn{2}{|c|}{ Rainfed ecosystem $(n=30)$} \\
\hline & No. of farmers & Percentage (\%) & No. of farmers & Percentage $(\%)$ \\
\hline \multicolumn{5}{|l|}{ Occupation } \\
\hline Agriculture as primary activity & 46 & 76.7 & 25 & 83.3 \\
\hline Agriculture as secondary activity & 14 & 23.3 & 5 & 16.7 \\
\hline \multicolumn{5}{|l|}{ Farm size } \\
\hline Marginal (< 1 ha) & 20 & 33.3 & 10 & 33.3 \\
\hline Small (1-2.5 ha) & 20 & 33.3 & 10 & 33.3 \\
\hline Big (>2.5 ha) & 20 & 33.3 & 10 & 33.3 \\
\hline \multicolumn{5}{|l|}{ Area under rice cultivation } \\
\hline Low ( $<25$ per cent of land holding) & 8 & 13.3 & 7 & 23.3 \\
\hline Medium (25-50 per cent of land holding) & 8 & 13.3 & 10 & 33.3 \\
\hline High ( $>50$ per cent of land holding) & 44 & 73.3 & 13 & 43.3 \\
\hline \multicolumn{5}{|l|}{ Social participation } \\
\hline Low & 16 & 26.7 & 12 & 40.0 \\
\hline Medim & 30 & 50.0 & 8 & 26.7 \\
\hline High & 14 & 25.4 & 10 & 33.3 \\
\hline \multicolumn{5}{|l|}{ Economic motivation } \\
\hline Low & 22 & 36.7 & 16 & 53.3 \\
\hline Medium & 20 & 33.3 & 7 & 23.3 \\
\hline High & 18 & 30.0 & 7 & 23.3 \\
\hline \multicolumn{5}{|l|}{ Cropping pattern } \\
\hline Single crop rice & 60 & 100.0 & 30 & 100.0 \\
\hline Double crop rice & 8 & 13.3 & 0.0 & 0.0 \\
\hline \multicolumn{5}{|l|}{ Input availability } \\
\hline Low & 14 & 23.3 & 14 & 46.7 \\
\hline Medium & 26 & 43.3 & 9 & 30.0 \\
\hline High & 20 & 33.3 & 7 & 23.3 \\
\hline \multicolumn{5}{|l|}{ Information seeking behavior } \\
\hline Low & 18 & 30.0 & 19 & 63.3 \\
\hline Medium & 20 & 33.3 & 6 & 20.0 \\
\hline High & 22 & 36.7 & 5 & 16.7 \\
\hline \multicolumn{5}{|l|}{ Labour availability } \\
\hline Low & 13 & 21.7 & 15 & 50.0 \\
\hline Medium & 43 & 71.7 & 8 & 26.7 \\
\hline High & 4 & 6.6 & 7 & 23.3 \\
\hline
\end{tabular}

Table 2: Adoption behaviour of farmers on recommended package of practices in rice.

\begin{tabular}{|c|c|c|c|c|}
\hline \multirow{2}{*}{$\begin{array}{l}\text { Specific recommended practices in rice } \\
\text { cultivation }\end{array}$} & \multicolumn{2}{|c|}{ Irrigated ecosystem $(n=60)$} & \multicolumn{2}{|c|}{ Rainfed ecosystem $(n=30)$} \\
\hline & No. of farmers & Percentage (\%) & No. of farmers & Percentage (\%) \\
\hline Variety & 53 & 88.3 & 21 & 70.0 \\
\hline Optimum seed rate & 40 & 66.7 & 20 & 66.7 \\
\hline
\end{tabular}


Journal of Progressive Agriculture, Vol.3, No. 2: Oct. 2012

\begin{tabular}{lllll}
\hline Seed treatmnet & 50 & 83.3 & 14 & 46.7 \\
Plant population & 40 & 66.7 & 12 & 40.0 \\
Soil testing & 20 & 33.3 & 10 & 33.3 \\
Diammonium phospahte to nursery & 32 & 53.3 & - & - \\
Application of fertilizer based soil testing & 15 & 25.0 & 7 & 23.3 \\
Micronutrient application & 29 & 48.3 & 11 & 36.7 \\
Split application of fertilizer & 30 & 50.0 & 14 & 33.3 \\
Pest management & 28 & 46.7 & 24 & 46.7 \\
Timely harvest & 52 & 86.6 & 80.0 \\
\hline
\end{tabular}

Table 3: Constraints faced by rice growing farmers in irrigated and rainfed rice

\begin{tabular}{|c|c|c|c|c|c|c|}
\hline \multirow[t]{2}{*}{ Constraints } & \multicolumn{3}{|c|}{ Irrigated ecosystem } & \multicolumn{3}{|c|}{ Rainfed ecosystem } \\
\hline & Frequency & Percentage (\%) & Rank & Frequency & Percentage (\%) & Rank \\
\hline \multicolumn{7}{|l|}{ Soil related constraints } \\
\hline Inadequate organic matter & 33 & 55.0 & II & 18 & 60.0 & II \\
\hline Low fertility of soil & 35 & 58.3 & I & 24 & 80.0 & I \\
\hline $\begin{array}{l}\text { Problematic soil (Acidic, saline and } \\
\text { alkaline) }\end{array}$ & 18 & 30.0 & IV & 10 & 33.3 & IV \\
\hline Micro nutrient deficiency in soil & 21 & 35.0 & III & 16 & 53.3 & III \\
\hline \multicolumn{7}{|l|}{ Crop management related constraints } \\
\hline Availability of improved variety & 20 & 33.3 & $\mathrm{~V}$ & 18 & 60.0 & $\mathrm{~V}$ \\
\hline Adopting correct spacing & 36 & 60.0 & IV & 17 & 56.7 & VI \\
\hline $\begin{array}{lll}\text { Adopting } & \text { specific } & \text { fertilizer } \\
\text { application } & & \end{array}$ & 48 & 80.0 & I & 23 & 76.7 & II \\
\hline Inadequate supply of water & 36 & 60.0 & IV & 26 & 86.7 & I \\
\hline Occurrence of weeds & 46 & 76.7 & II & 20 & 66.7 & IV \\
\hline Higher pest incidence & 38 & 63.3 & III & 21 & 70.0 & III \\
\hline Using of aged seedlings & 20 & 33.3 & $\mathrm{~V}$ & - & - & - \\
\hline \multicolumn{7}{|l|}{ Socio-economic related constraints } \\
\hline High cost of inputs & 41 & 68.3 & III & 20 & 66.7 & IV \\
\hline High cost of Labour & 46 & 76.7 & I & 26 & 86.7 & I \\
\hline Non-availability of credit & 40 & 66.7 & IV & 25 & 83.3 & II \\
\hline High rate of credit & 42 & 70.0 & II & 21 & 70.0 & III \\
\hline $\begin{array}{l}\text { Non-availability of farming } \\
\text { implements }\end{array}$ & 30 & 50.0 & VI & 20 & 66.7 & IV \\
\hline Scattered land holding & 32 & 53.3 & $\mathrm{~V}$ & 12 & 40.0 & VI \\
\hline Lack of transport facilities & 18 & 30.0 & VII & 21 & 70.0 & III \\
\hline $\begin{array}{l}\begin{array}{l}\text { Contract system for cultural } \\
\text { operations }\end{array} \\
\text { Pation }\end{array}$ & 41 & 68.3 & III & 19 & 63.3 & $\mathrm{~V}$ \\
\hline \multicolumn{7}{|l|}{ Other Constraints } \\
\hline Lack of awareness of technologies & 34 & 60.0 & I & 18 & 60.0 & II \\
\hline Lack of training facilities & 36 & 56.7 & II & 19 & 63.3 & I \\
\hline Lack of union & 16 & 26.7 & III & 13 & 43.3 & III \\
\hline
\end{tabular}

\section{REFERENCES}

Balasubramani, N., Swathilekshmi, P.S and Chandrakandan, K. 2005. A study on the yield gap analysis in paddy, in the erode district of Tamil Nadu. Asian Journal of Extension Education. 25: 44-51.

Chaudhary, R.C. and Tran, D.V. 1999. Can Africa be the future rice supplier for Asia. In: Proc. $4^{\text {th }}$ Asian
International Rice Conference, Cebu, 1999, Philippines. p. 29.

Paroda, R.S. 1998. Priorities and opportunities for rice production and consumption in India for self-sufficiency. Sustainability of rice in the global food system : 357-390. 
Singh, P.K and Varshaney, J.G. 2010. Adopation level and constraints in rice production technology. Indian Research Journal of Extension Education. 10(1): 91-94.
Veeraswamy. S., Satpathy, C and Rao, G.A. 2003. Constraints of Rice production in Orissa. Indian Journal of Exention Education. 33 (142): 58-63. 